\title{
Port Site Infection
}

National Cancer Institute

\section{Source}

National Cancer Institute. Port Site Infection. NCI Thesaurus. Code C122425.

An infection at an anatomic location used for vascular access. 